which the everglade kite subsists in Florida is Pomacea paludosa, not $P$. paludis. The photograph captioned "The Everglades, Florida" is a view of mangrove swamp forest along the lower Shark River, a tideway of the Everglades estuary, near the Gulf of Mexico. This area is not typical of the Everglades, which is chiefly a freshwater marsh with small islands of trees, nor is it everglade kite habitat.

Yours faithfully,

PaUL W. Sykes, jun.

William B. Robertson, jun.

US Department of the Interior,

Bureau of Sport Fisheries and Wildlife,

Patuxent Wildlife Research Center,

Endangered Wildlife Research Program,

Delray Beach, Florida, USA.

US Department of the Interior,

National Park Service,

Everglades National Park,

Homestead, Florida, USA.

\section{The McCarthy Study}

Sin,-The McCarthy Report recognizes from the outset that attempts to predict the absolute number of scientists and technologists required by the British economy are most likely to be unsuccessful and concentrates instead on attempting to predict the relative proportion of specialist scientists to generalist scientists. Unfortunately, the report does this by averaging over different disciplines in an inadmissible way. In fact, if one breaks the result down into different disciplines the result, including management in the research and development figures, is as follows:

T'able 1. EMPLOYMENT OF SCIENTISTS AND ENGINEERS IN AMERIOAN INDUSTRY BY DISCIPLINE FOR 1962 AND 1963*

\begin{tabular}{|c|c|c|c|c|c|}
\hline 1962 & Total & Engineers & Physicists & Chemists & Mathns. \\
\hline Allindustries & 851,600 & 684,600 & 13,900 & 81,600 & 14,700 \\
\hline $\begin{array}{l}\text { R\&D } \\
\text { Per cent," }\end{array}$ & 303,800 & 220,900 & 11,800 & 45,500 & 7,800 \\
\hline $\begin{array}{l}\text { Per cent } \\
\text { Manufacturing }\end{array}$ & 630.400 & $\begin{array}{r}32 \\
489.800\end{array}$ & $\begin{array}{r}85 \\
11.400\end{array}$ & $\begin{array}{r}56 \\
69.300\end{array}$ & $\begin{array}{r}53 \\
9800\end{array}$ \\
\hline $\mathrm{R} \& \mathrm{D}$ & 267,200 & 194,600 & 9,700 & 40,500 & 6,100 \\
\hline Per cent & 42 & 40 & 85 & 58 & 62 \\
\hline \multicolumn{6}{|l|}{1963} \\
\hline All industries & 871,400 & 711,600 & 14,500 & 74,300 & 20,400 \\
\hline $\mathrm{R} \& \mathrm{D}$ & 344,900 & 260,900 & 12,500 & 43,800 & 10,900 \\
\hline Per cent & 40 & 37 & 86 & 59 & 53 \\
\hline Manufacturing & 653,500 & 521,600 & 11,000 & 65,800 & 12,600 \\
\hline $\mathrm{R} \& \mathrm{D}$ & 300,800 & 230,300 & 9,600 & 39,100 & 7,500 \\
\hline Per cent & 46 & 44 & 87 & 59 & 60 \\
\hline
\end{tabular}

NSF US Department of Labour, Bureau of Labour Statistics.

From the table it can be seen that as far as physics is concerned, and to a lesser extent chemistry and mathe matics, the great majority should be trained as specialists so that unless we are able to predict absolute numbers we are no further forward. The breakdown of the figures for the United Kingdom into various disciplines does not seem to be available, but as far as basic research is concerned perhaps one might find a clue by cxamining the sources of papers submitted to the Physical Review and to corresponding British journals-- P'roceedings of the Physical Society and Philosophical Magazine.

$$
\text { Table } 2 .
$$

\begin{tabular}{|c|c|c|c|c|c|c|}
\hline Classification & $\begin{array}{l}\text { Educt. } \\
\text { (1) }\end{array}$ & $\begin{array}{l}\text { Govt. } \\
\text { Lab (2) }\end{array}$ & $\underset{(3)}{\text { Industry }}$ & $1+2$ & $\begin{array}{l}\text { Joint } \\
1+3\end{array}$ & $2+3$ \\
\hline $\begin{array}{l}\text { UK (Proc. Phys. Soc. } \\
\text { and Phil. Mag.)\% } \\
\text { USA (Phys. Rev.) \% }\end{array}$ & $\begin{array}{l}77 \\
67\end{array}$ & $\begin{array}{r}14 \\
9\end{array}$ & $\begin{array}{r}2 \\
17\end{array}$ & $\begin{array}{l}4 \\
2 \cdot 3\end{array}$ & $\begin{array}{l}0 \cdot 6 \\
3 \cdot 7\end{array}$ & $\overrightarrow{0.5}$ \\
\hline
\end{tabular}

The results are set out in Table 2 for a moro or less random sample of issues of the various journals. It may well be true that a major part of the contribution from
American industry to the Physical Review represents prestige projects, but presumably this is intended to attract good physicists into industry and subsequently to interest them in more immediately profitable rescarch. In conclusion, until some more satisfactory method is found for estimating future requirements of trained manpower, it would seem to be very unwise to reduce the number of spccialist physicists in favour of generalists.

Yours faithfully,

\section{G. N. FowLer}

University of Exeter,

Department of Physics,

The Queen's Drive,

Exeter.

ERratum. A mistake occurred in the article "Spectral Properties of the X-Ray Objects $G X 3+1, G X 354-5$ and Sco XR-1" by G. Buselli et al. (Nature, 219, 1124; 1968), because of an inadvertent alteration made in the Nature office to the original typescript. It was stated in the article that the spectra of $G X 3+1, G X 354-5$ and Sco $X R$-I suggest that these three $\mathrm{X}$-ray objects are similar to one another. The data are at variance with this statement, and in fact the authors' conclusion is that $G X 3+1$, Cyg $X R-1$ and Tau $X R-1$ possess similar spectra, and are probably due to similar celestial objects. One of the authors, K. G. MeCracken, has written to stress how this conclusion was reached:

"Our measurements of $G X 3+1$ above $20 \mathrm{keV}$ show a good fit to a power law photon number spectrum given by

$$
\frac{\mathrm{d} N}{\mathrm{~d} E}=3.4 E^{-2.0} \pm 0.2 \text { photons } \mathrm{cm}^{-2} \mathrm{~s}^{-1} \mathrm{keV}^{-1}
$$

which, when extrapolated to lower energies, is in reasonable agreement with the results of Gursky et al. (Ap. $J$., 150, L75; 1967) and Bradt et al. (Ap. J., 152, 1005; 1968). Furthermore, we note that other workers have obtained power law photon number spectra for Tau XR-1 and Cyg XR-1; for example, Peterson et al. (Proc. Tenth Intern. Conf. Cosmic Rays, Calgary; 1968) quoto

$$
\frac{\mathrm{d} N}{\mathrm{~d} E}=\left\{\begin{array}{lll}
3.50 & E^{-1.91} & \text { Tau } X R-1 \\
3.58 & E^{-1.93} \pm 0.2 & \text { Cyg } X R-1
\end{array}\right.
$$

The spectral exponents in the spectra of $G X 3+1$, Tau $X R-1$ and Cyg $X R-1$ are statistically identical, while there are other objects known to exhibit markedly different spectral characteristics (our paper shows that Sco $X R-l$.

for example, has $\frac{\mathrm{d} N}{\mathrm{~d} E} \sim E^{-3.8} \pm 0.4$ above $20 \mathrm{keV}$ ). This sug-

gests that the three X-ray objects $G X 3+1$, Tau $X R-1$ and Cyg $X R-1$ are physically similar to one another. The fact that Tau $X R-1$ is known to be a supernova remnant, the spectral shape itself suggesting that the $X$-ray cmission from Tau $X R$-I may be due to magnetic bremsstrahlung, suggests a similar explanation for $G_{x}^{y} X 3+1$ and Cyg XR.1".

Corrigrndum. The last paragraph of the article "Surfaco Forces: Direct Measurement of Normal and Retarded van der Waals Forces" by D. Tabor and R. H. S. Winterton (Nature, 219, 1120; 1968) should read: We thank Professor F. P. Bowden for his constant interest in this work, which was carried out with the valuable support of the Gas Council. One of us (R.H.S.W.) thanks the SRC for his research studentship. 